Article

\title{
Are Renewables as Friendly to Humans as to the Environment?: A Social Life Cycle Assessment of Renewable Electricity
}

\author{
Shutaro Takeda ${ }^{1, * \mathbb{C}}$, Alexander Ryota Keeley ${ }^{2}$, Shigeki Sakurai ${ }^{1}$, Shunsuke Managi ${ }^{2}$ and \\ Catherine Benoît Norris ${ }^{3}$ \\ 1 Graduate School of Advanced Integrated Studies in Human Survivability, Kyoto University, \\ Kyoto 606-8306, Japan; sakurai.shigeki.2c@kyoto-u.ac.jp \\ 2 Department of Urban and Environmental Engineering, Kyushu University, Fukuoka 819-0395, Japan; \\ keeley.ryota.alexander.416@m.kyushu-u.ac.jp (A.R.K.); managi.s@gmail.com (S.M.) \\ 3 Extension School, Harvard University, Cambridge, MA 02138, USA; catherine@socialhotspot.org \\ * Correspondence: takeda.shutarou.55r@kyoto-u.jp
}

Received: 8 February 2019; Accepted: 1 March 2019; Published: 5 March 2019

\begin{abstract}
The adoption of renewable energy technologies in developing nations is recognized to have positive environmental impacts; however, what are their effects on the electricity supply chain workers? This article provides a quantitative analysis on this question through a relatively new framework called social life cycle assessment, taking Malaysia as a case example. Impact assessments by the authors show that electricity from renewables has greater adverse impacts on supply chain workers than the conventional electricity mix: Electricity production with biomass requires $127 \%$ longer labor hours per unit-electricity under the risk of human rights violations, while the solar photovoltaic requires $95 \%$ longer labor hours per unit-electricity. However, our assessment also indicates that renewables have less impacts per dollar-spent. In fact, the impact of solar photovoltaic would be $60 \%$ less than the conventional mix when it attains grid parity. The answer of "are renewables as friendly to humans as to the environment?" is "not-yet, but eventually."
\end{abstract}

Keywords: renewable energy; supply chain; social responsibility; social life cycle assessment; labor conditions; Malaysia; solar PV; Biomass; Hydro

\section{Introduction}

Countries around the globe are competing for the increased adoption of renewable energy technologies, and developing nations are leading this trend in the aim of meeting the growing electricity demand in a sustainable manner. Various studies have demonstrated the positive environmental externalities and macroeconomic effects of such initiatives, including their impacts on GDP, unemployment, and balance of trade [1-4]. However, there are fewer studies that examine the social impacts of renewable energy development quantitatively. This should be a point of concern for developing nations, where worker often suffer from poor labor conditions as part of global supply chains. For this reason, the adoptions of renewable energy technologies should be assessed not only from environmental and economic perspectives but also from the social responsibility perspective as well.

The question the authors intend to discuss through this analysis is, "are renewable energy technologies as friendly to humans as to the environment?" This analysis tries to answer this substantial question quantitatively with the help of a relatively new framework called the social life cycle assessment. The rest of the article is structured as follows in conformity with ISO 14040/14044. Section 2 explains the goal 
and scope, methods and data employed in this analysis. Section 3 presents the results of the impact assessment. Finally, based on the results, Section 4 presents the interpretation and conclusions.

\section{Methods}

\subsection{Goal and Scope}

The goal of this analysis is to assess the adverse social impacts of renewable electricity production in a developing nation, and to compare them to that of the conventional electricity production mix. For this, the authors choose Malaysia as the case example. Estimated to increase its gross domestic product at about $5-6 \%$ annually until 2020, the electricity generation in Malaysia is also expected to grow significantly with $3.5 \%$ annual growth [5]. To meet the growing electricity demand in a sustainable manner, the Malaysian government has launched the National Renewable Energy Policy in 2010, setting a renewable energy target of $11 \%$ of the total energy mix by 2020 . Local policymakers acknowledge the need to capture the environmental, economic, and social impacts of renewable energy development to accelerate this rapid expansion, which push them to publish statistical data on renewable energy projects for research purposes. This makes the country a very fitting case for this analysis. While this analysis focuses on Malaysia, the results should be representative of how renewable development in southeast Asian nations would affect the labor in the electricity supply chain, due to the similar renewable cost structures in these nations.

The products assessed in this analysis were electricity from solar PV, biomass power, hydropower and the current electricity production mix in Malaysia. The system considered in this study was cradle-to-gate, or the product life cycle from resource production to the electricity production but without consideration of waste disposal or decommission after the life of the plant.

\subsection{Social Life Cycle Assessment}

Life cycle assessment (LCA) is a commonly-used analytical framework to quantify the impact of a product or a service over its lifetime. LCA has been primarily applied to the assessment of environmental emissions, most notably to compare the carbon dioxide emissions. Social life cycle assessment, or S-LCA, is an emerging framework to assess the social impacts of products or services through LCA. S-LCA has been developed in conformity to the international standard of LCA, ISO14040/44, and its first guideline was published by United Nations Environmental Programme and Society of Environmental Toxicology and Chemistry [6]. S-LCA looks into social impact on the workers in the product supply chain, for categories including health and safety, human rights, cultural heritage, working conditions, and governance. Results from S-LCA enable the identification of areas of improvement and comparison of products from the standpoint of their social performance, which could be valuable for both policymaking and corporate decision-making is to facilitate the enhancement of social conditions.

For its helpfulness in policymaking, S-LCA has been increasingly applied to various products and services in the last several years, including tourism, farming, and recycling systems [7-10]. However, few have applied S-LCA to assess the impact of the introduction of science and technology; in fact, none of the preceding studies have applied the framework to make a comparison of different electricity generation systems.

The authors believe S-LCA can be an ideal framework to quantitatively discuss the intersections between science and society that have policy implications. S-LCA can be especially beneficial in the energy sector, where the supply chains are cross-border and the interactions between human rights, standard of living and natural resources are complex. The authors hope that this analysis fills this gap.

\subsection{Social Hotspots Database}

Social Hotspots Database (SHDB) was used in this analysis as the database to calculate the social impact of the supply chain of renewable electricity. SHDB is a follow-up initiative to the UNEP/SETAC 
Guidelines developed by New Earth, and is the first commercially available database for S-LCA to enable the identification of the social impact along the product supply chain [11,12]. SHDB is based on the global trade analysis project (GTAP) input-output model, and the database is composed of sector and country-specific tables of indicators for 57 sectors in 133 countries to support identifying hotspots in supply chains based on potential social impacts. SHDB enables the efficient application of S-LCA by providing data for: (1) labor intensity in worker hours per unit process; (2) risk for, or opportunity to affect relevant social themes or sub-categories related to human rights, labor rights, and decent work, governance and access to community services; and (3) gravity of a social issue [13]. With SHDB, social impacts of a product system can be measured in "Risk Hours (RH)." Risk Hours represents the weighted cumulative labor hours where workers in the supply chain may be at risk for each specific social issue. The authors used the 2013 version of SHDB, which is based on the GTAP model published in 2008 and social risk data from years 2010-2012 [14]. Considering major renewable energy development projects in Malaysia took place around 2011 [15], the 2013 SHDB would provide timely valid risk data for this analysis.

\subsection{Impact Assessment Method}

SHDB provides an impact assessment method for S-LCA named Social Hotspot Index (SHI). SHDB and SHI have 22 midpoint impact categories (called Social Themes) and five endpoint impact categories (called Social Category) as illustrated in Figure 1. For each theme and for many indicators, impact subcategories called Characterized Social Issues are available as summarized in Table 1.

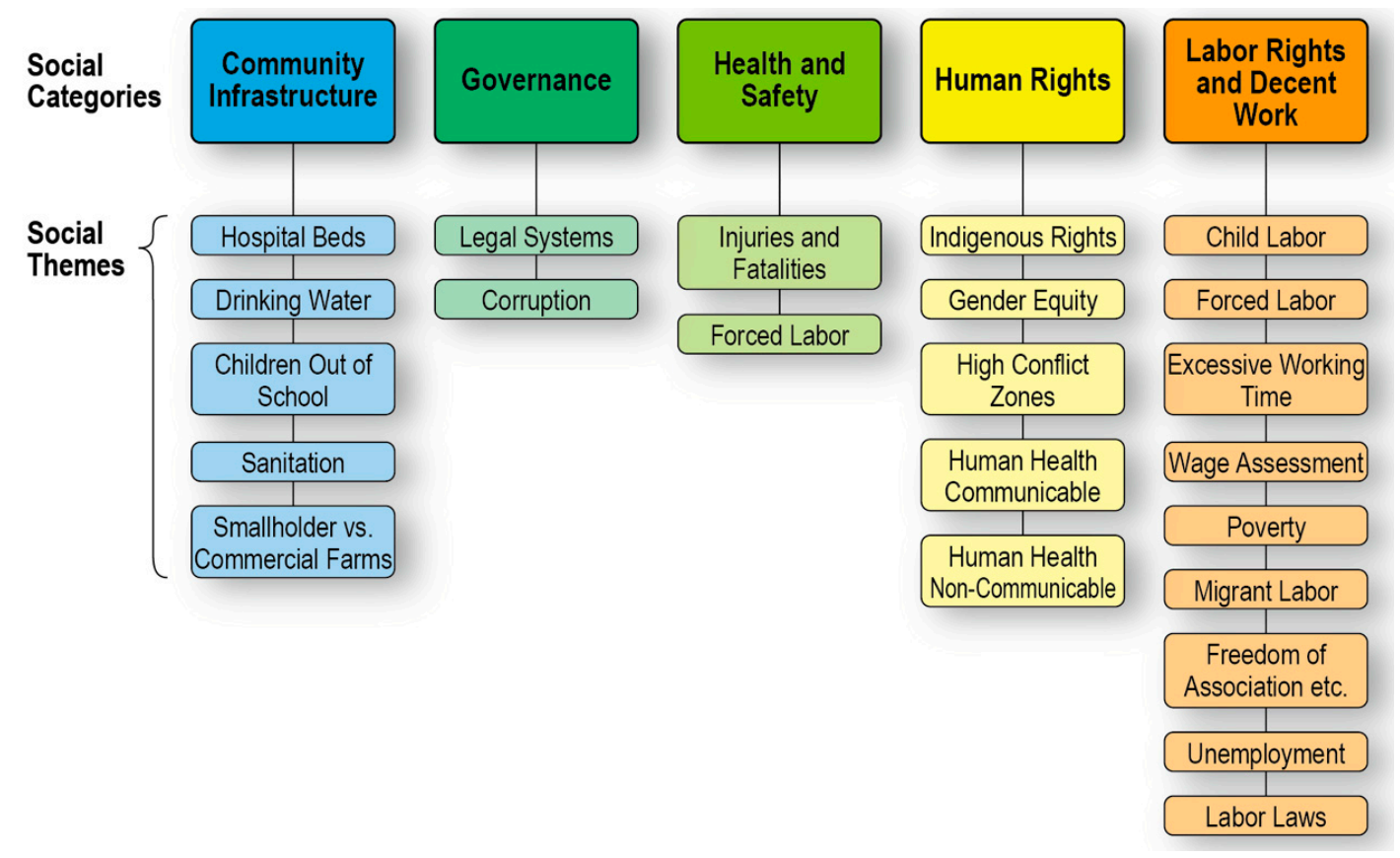

Figure 1. Social Hotspots Database midpoint and endpoint impact categories [16].

Table 1. Characterized Social Issues by Social Theme and Category [13].

\begin{tabular}{cll}
\hline Social Theme (Name of Table) & \multicolumn{1}{c}{ Data Indicator } & \multicolumn{1}{c}{ Characterized Issue } \\
\hline \multirow{3}{*}{ Labor Laws/Conventions } & Number of Labor Laws & Risk of Country not passing Labor Laws \\
\cline { 2 - 3 } & Number of Labor Laws by sector & $\begin{array}{l}\text { Risk of Country not passing Labor Laws by } \\
\text { Sector }\end{array}$ \\
\cline { 2 - 3 } & $\begin{array}{l}\text { Number of Labor Conventions ratified (out } \\
\text { of } 81 \text { possible) }\end{array}$ & $\begin{array}{l}\text { Risk of Country not adopting Labor } \\
\text { Conventions }\end{array}$ \\
\cline { 2 - 3 } & $\begin{array}{l}\text { Number of Labor Conventions ratified by } \\
\text { sector }\end{array}$ & $\begin{array}{l}\text { Risk of Country not adopting Labor } \\
\text { Conventions by Sector }\end{array}$ \\
\cline { 2 - 3 } & Year of last Minimum Wage Update & Risk of Minimum Wage not being updated \\
\hline
\end{tabular}


Table 1. Cont

\begin{tabular}{|c|c|c|}
\hline Social Theme (Name of Table) & Data Indicator & Characterized Issue \\
\hline \multirow{8}{*}{ Wage Assessment } & Minimum Wages (USD) & \multirow{2}{*}{$\begin{array}{l}\text { Risk of Country Average Wage being < } \\
\text { Minimum Wage }\end{array}$} \\
\hline & Average Unskilled Wages (USD) in country & \\
\hline & Non-Poverty Guideline (USD) & \multirow{2}{*}{$\begin{array}{l}\text { Risk of Country Average Wage being < } \\
\text { Non-Poverty Guideline }\end{array}$} \\
\hline & Average Unskilled Wages (USD) in country & \\
\hline & Minimum Wages (USD) & \multirow{2}{*}{$\begin{array}{l}\text { Risk of Sector Average Wage being < } \\
\text { Minimum Wage }\end{array}$} \\
\hline & Average Unskilled Wages (USD) by sector & \\
\hline & Non-Poverty Guideline (USD) & \multirow{2}{*}{$\begin{array}{l}\text { Risk of Sector Average Wage being < } \\
\text { Non-Poverty Guideline }\end{array}$} \\
\hline & Average Unskilled Wages (USD) by sector & \\
\hline Population living in Poverty & Percent of Population living on $<\$ 2 /$ day & Risk of Population living on $<\$ 2 /$ day \\
\hline \multirow{2}{*}{ Child Labor } & Child Labor \% in country & Risk of Child Labor in country \\
\hline & Child Labor \% by sector & Risk of Child Labor by sector \\
\hline \multirow{2}{*}{ Forced Labor } & Qualitative & Risk of Forced Labor in country \\
\hline & Qualitative & Risk of Forced Labor by sector \\
\hline \multirow[t]{2}{*}{ Excessive Working Time } & Percent working $>48 \mathrm{~h} /$ week in country & $\begin{array}{l}\text { Risk of Population working }>48 \mathrm{~h} / \text { week in } \\
\text { country }\end{array}$ \\
\hline & Qualitative & $\begin{array}{l}\text { Risk of Population working }>48 \mathrm{~h} / \text { week by } \\
\text { Sector }\end{array}$ \\
\hline \multirow{3}{*}{$\begin{array}{l}\text { Freedom of Association, Collective } \\
\text { Bargaining, Right to Strike }\end{array}$} & Qualitative & $\begin{array}{l}\text { Risk of not having Freedom of Association } \\
\text { Rights }\end{array}$ \\
\hline & Qualitative & $\begin{array}{l}\text { Risk of not having Collective Bargaining } \\
\text { Rights }\end{array}$ \\
\hline & Qualitative & Risk of not having the Right to Strike \\
\hline \multirow{2}{*}{ Unemployment } & Unemployment Average \% from 2000-2009 & Risk of High Unemployment in country \\
\hline & Unemployment \% by sector & Risk for High Unemployment by sector \\
\hline \multirow{7}{*}{ Legal System } & $\begin{array}{l}\text { World Bank Worldwide Governance } \\
\text { Indicator-Rule of Law }\end{array}$ & \multirow{7}{*}{ Risk of Fragility in Legal System } \\
\hline & $\begin{array}{l}\text { Bertelsmann Transformational Index - Rule } \\
\text { of Law, Independent Judiciary }\end{array}$ & \\
\hline & $\begin{array}{l}\text { CIRI Human Rights Index-Independent } \\
\text { Judiciary }\end{array}$ & \\
\hline & $\begin{array}{l}\text { Global Integrity Index-Judicial } \\
\text { Accountability }\end{array}$ & \\
\hline & Global Integrity Index-Rule of Law & \\
\hline & Global Integrity Index-Law Enforcement & \\
\hline & World Justice Project-Average & \\
\hline \multirow{6}{*}{ Indigenous Rights } & Presence of indigenous population, $X$ & Not characterized \\
\hline & Indigenous Population, $\%$ & Amount of Indigenous Population \\
\hline & $\begin{array}{l}\text { ILO Convention adopted for Indigenous } \\
\text { Population, } \mathrm{Y} \text { or } \mathrm{N}\end{array}$ & \multirow{2}{*}{$\begin{array}{l}\text { Risk of country not adopting Indigenous } \\
\text { ILO convention and UN Declaration }\end{array}$} \\
\hline & $\begin{array}{l}\text { UN Declaration for Indigenous Population, } \\
\text { endorsed }(\mathrm{Y}) \text {, abstained }(\mathrm{A}) \text {, against }(\mathrm{N})\end{array}$ & \\
\hline & $\begin{array}{l}\text { Number of Laws enacted to protect } \\
\text { Indigenous Population }\end{array}$ & $\begin{array}{l}\text { Risk of country not passing Laws to protect } \\
\text { Indigenous Population }\end{array}$ \\
\hline & Qualitative & $\begin{array}{l}\text { Risk for Indigenous Rights Infringements } \\
\text { by Sector }\end{array}$ \\
\hline \multirow{9}{*}{ Gender Equity } & Social Institutions and Gender Index & \multirow{7}{*}{ Risk of Gender Inequity } \\
\hline & Global Gender Gap & \\
\hline & World Bank Gender Development Indicator & \\
\hline & World Bank Gender Empowerment Index & \\
\hline & CIRI Human Rights Index-Economic & \\
\hline & CIRI Human Rights Index-Political & \\
\hline & CIRI Human Rights Index-Social & \\
\hline & $\begin{array}{l}\text { Adolescent fertility rate (births per } 1000 \\
\text { women ages 15-19) }\end{array}$ & Not characterized \\
\hline & Fertility rate, total (births per woman) & Not characterized \\
\hline
\end{tabular}


Table 1. Cont.

\begin{tabular}{|c|c|c|}
\hline Social Theme (Name of Table) & Data Indicator & Characterized Issue \\
\hline & $\begin{array}{l}\text { Share of women employed in the } \\
\text { nonagricultural sector (\% of total } \\
\text { nonagricultural employment) }\end{array}$ & Not characterized \\
\hline & $\begin{array}{l}\text { \% Unemployment, ( } \% \text { of female labor force } \\
\text { unemployed } / \% \text { of male labor force } \\
\text { unemployed) }\end{array}$ & Not characterized \\
\hline & $\%$ of women workers vs. men by sector & Risk of Gender Inequity by sector \\
\hline \multirow{8}{*}{ High Conflict Zones } & $\begin{array}{l}\text { Heidelberg Conflict Barometer-\# of } \\
\text { conflicts }\end{array}$ & \multirow{7}{*}{ Risk for High Conflict } \\
\hline & $\begin{array}{l}\text { Heidelberg Conflict Barometer-maximum } \\
\text { intensity of conflicts }(1-5)\end{array}$ & \\
\hline & $\begin{array}{l}\text { Heidelberg Conflict Barometer-change in } \\
\text { conflicts (positive = worsening) }\end{array}$ & \\
\hline & Number of Refugees-UN Refugee Agency & \\
\hline & Center for Systemic Peace Indicator & \\
\hline & Minority Rights Group Indicator & \\
\hline & $\begin{array}{l}\text { Top Risers from last year in Minority Rights } \\
\text { Group Indicator, X }\end{array}$ & \\
\hline & Qualitative & Risk for High Conflict specific to sectors \\
\hline \multirow{11}{*}{$\begin{array}{l}\text { Human Health-Communicable } \\
\text { Diseases and Other Health Risks } \\
\text { besides Disease }\end{array}$} & Life expectancy at birth (years) 2008 & Risk of low life expectancy \\
\hline & $\begin{array}{l}\text { Mortality rates for injuries (per 100,000 } \\
\text { population) } 2004\end{array}$ & Risk of high mortality rates due to injury \\
\hline & $\begin{array}{l}\text { Proportion of undernourished \% of total } \\
\text { population, }(-)=<5 \% 2005-2007\end{array}$ & Risk of high undernourishment \\
\hline & $\begin{array}{l}\text { Deaths due to indoor and outdoor air and } \\
\text { water pollution (per one million population) } \\
2004\end{array}$ & Risk of death due to air and water pollution \\
\hline & $\begin{array}{l}\text { Population affected by natural disasters, } \\
\text { average per year per million } 2000-2009\end{array}$ & Risk of death due to natural disasters \\
\hline & $\begin{array}{l}\text { Cases of HIV (per } 1000 \text { adults } 15-49 \text { years) } \\
2010\end{array}$ & Risk of HIV 2010 \\
\hline & $\begin{array}{l}\text { Cases of Tuberculosis (per 100,000 } \\
\text { population) } 2008\end{array}$ & Risk of Tuberculosis 2008 \\
\hline & $\begin{array}{l}\text { Cases of Malaria (per 100,000 population) } \\
2008\end{array}$ & Risk of Malaria 2008 \\
\hline & $\begin{array}{l}\text { Cases of Dengue Fever (per 100,000 } \\
\text { population) } 2005\end{array}$ & Risk of Dengue Fever, 2005 \\
\hline & Cases of Cholera 2008 & Risk of Cholera 2008 \\
\hline & $\begin{array}{l}\text { Mortality rates from communicable } \\
\text { diseases (per 100,000 population) } 2004\end{array}$ & $\begin{array}{l}\text { Risk of mortality from communicable } \\
\text { diseases }\end{array}$ \\
\hline \multirow{3}{*}{ Children Out of School } & Children out of School—male & Risk of Children not attending School-male \\
\hline & Children out of School—female & $\begin{array}{l}\text { Risk of Children not attending } \\
\text { School-female }\end{array}$ \\
\hline & Children out of School—total & Risk of Children not attending School-total \\
\hline \multirow{3}{*}{ Access to Improved Drinking Water } & $\begin{array}{l}\text { Access to Improved Drinking Water, } \\
\% \text {-rural }\end{array}$ & $\begin{array}{l}\text { Risk of not having access to Improved } \\
\text { Drinking Water-rural }\end{array}$ \\
\hline & $\begin{array}{l}\text { Access to Improved Drinking Water, } \\
\% \text { - urban }\end{array}$ & $\begin{array}{l}\text { Risk of not having access to Improved } \\
\text { Drinking Water-urban }\end{array}$ \\
\hline & $\begin{array}{l}\text { Access to Improved Drinking Water, } \\
\% \text { - total }\end{array}$ & $\begin{array}{l}\text { Risk of not having access to Improved } \\
\text { Drinking Water-total }\end{array}$ \\
\hline \multirow{3}{*}{ Access to Improved Sanitation } & Access to Improved Sanitation, $\%$-rural & $\begin{array}{l}\text { Risk of not having access to Improved } \\
\text { Sanitation-rural }\end{array}$ \\
\hline & Access to Improved Sanitation, $\%$-urban & $\begin{array}{l}\text { Risk of not having access to Improved } \\
\text { Sanitation-urban }\end{array}$ \\
\hline & Access to Improved Sanitation, $\%$ 一total & $\begin{array}{l}\text { Risk of not having access to Improved } \\
\text { Sanitation-total }\end{array}$ \\
\hline Access to Hospital Beds & Access to Hospital Beds—\# beds/1000 pop & Risk of not having Access to Hospital Beds \\
\hline
\end{tabular}


Based on the inventory data for 705 indicators, SHDB weights and calculates the SHI as Equation (1).

$$
S H I=\frac{\sum_{T=1}^{n} R_{a v g} W}{\sum_{T=1}^{n} R_{\max } W}
$$

where $\mathrm{n}$ represents the number of Social Themes, $R_{\text {avg }}$ represents the average risk of the Social Theme, $R_{\max }$ represents the maximum risk for a theme and $\mathrm{W}$ represents the weighting factor [17]. The weighting factor is assigned based on the risk levels: 10 for very high, 5 for high, 1 for medium and 0.1 for low. For normalization of the results, the SHDB simply weights all Social Categories equally.

This social life cycle impact assessment methodology is illustrated by Shemfe et al. as Figure 2 [17]. The 22 midpoint impact categories of SHDB are part of the international auditable certification for the promotion of labor rights, SA8000 [18]. Although currently there are no ISO norms specifically for S-LCA, SHDB is based on the principles of LCA ISO norms (ISO 14040/14044) and is in conformity to the UNEP/SETAC Guidelines [19].

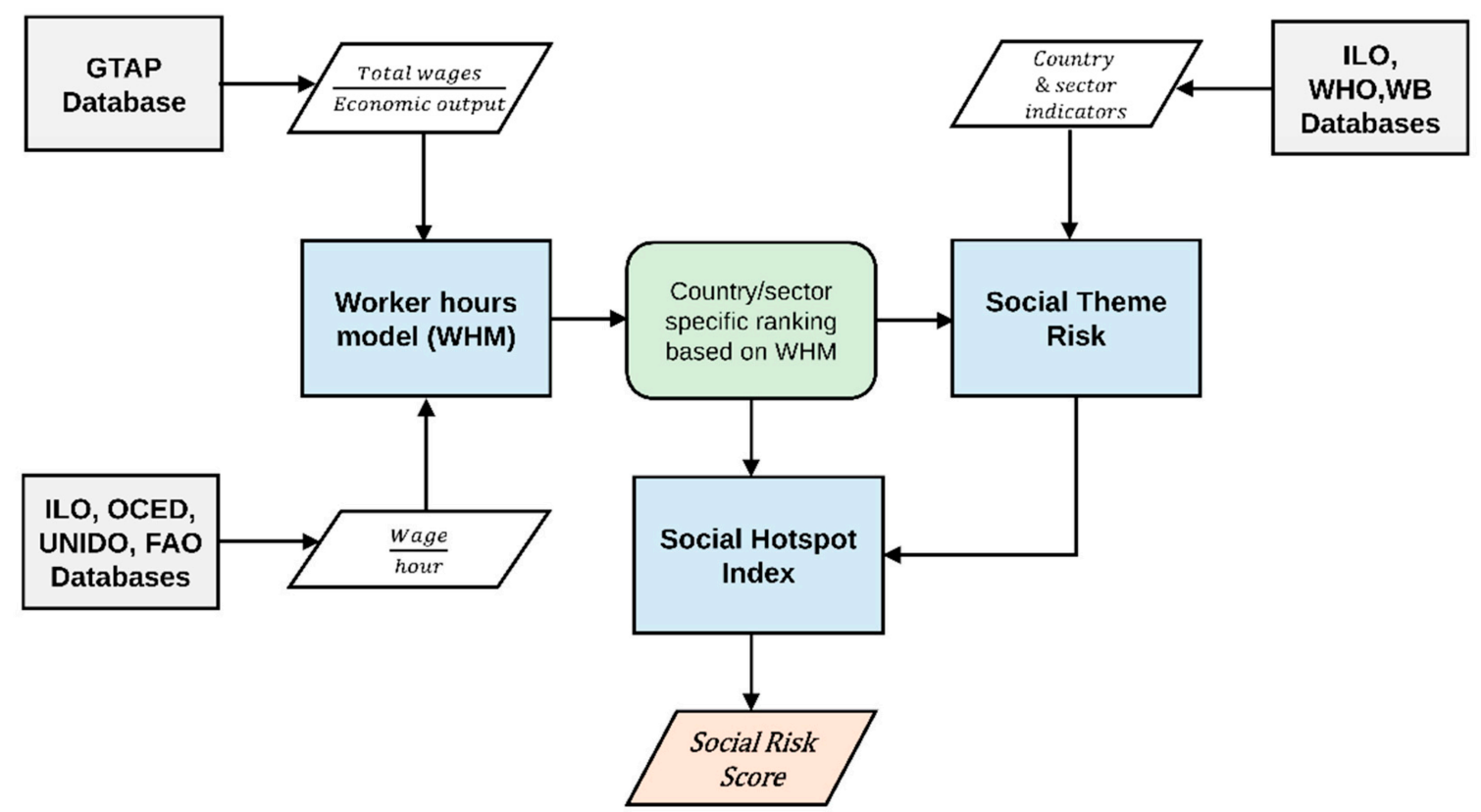

Figure 2. Methodology of the Social Life Cycle Impact Assessment with SHDB [17].

\subsection{Data Collection}

The authors collected the life-cycle cost structure data for renewable energy sources in Malaysia from a report published by ASEAN Centre for Energy in 2016 [20], which reports the levelized costs of electricity (LCOE) of renewable electricity based on surveys of 21 solar photovoltaic (PV), five biomass, and five hydro power plants in Malaysia. In this report, LCOE is defined as the net present value of the unit cost of electricity over a lifetime, calculated by dividing the net present value of all costs over the lifetime of the project by the total electricity output of the project [20]. Due to the difficulties in assuming different lifetimes for every project, a lifetime of 20 years was assumed for all plants. A discount rate of $10 \%$ is used for all projects, which applies to social impacts as well. Each cost breakdown is then assigned a GTAP model section code as well as a harmonized commodity description and coding systems 6-digit trade category code (HS-6) by the authors.

The countries-of-origins data for each capital expenditure (CAPEX) sector were collected from the economic atlas, which are derived from the countries reporting to the United Nations Statistical Division (COMTRADE), and raw trade data on services are from the International Monetary Fund (IMF) Direction of Trade Statistics database [21]. The authors referenced the import trade statistics of Malaysia in 2016 for each respective HS-6 code, with the cut-off importing a share value of $5 \%$. 


\subsection{Product Modeling}

Based on the data collection method detailed in the previous section, the levelized cost structure of each renewable electricity in Malaysia in 2016 is modeled as Figure 3. For solar PV, plants are classified based on their capacity as small (below $100 \mathrm{~kW}$ output), medium (above $100 \mathrm{~kW}$ but below $1000 \mathrm{~kW}$ ), and large (above $1000 \mathrm{~kW}$ ). For biomass and hydro power electricity, the cost modeling was based on the country average data. The costs reported by ASEAN Centre for Energy were converted into USD2002 by multiplying by 0.74957 to adjust for inflation. Because of the lack of necessary trade data, the mineral products from Brunei were calculated as the ones from Malaysia. Since the mineral products from Brunei only amounts to $0.2 \%$ of the LCOE of hydroelectricity, this change does not affect the results significantly. For the conventional electricity model in Malaysia, the default product model provided by SHDB for electricity in Malaysia was used without modifications. (The cost structures and the country-of-origins models are attached as Supplementary Materials as Tables S1 and S2.)

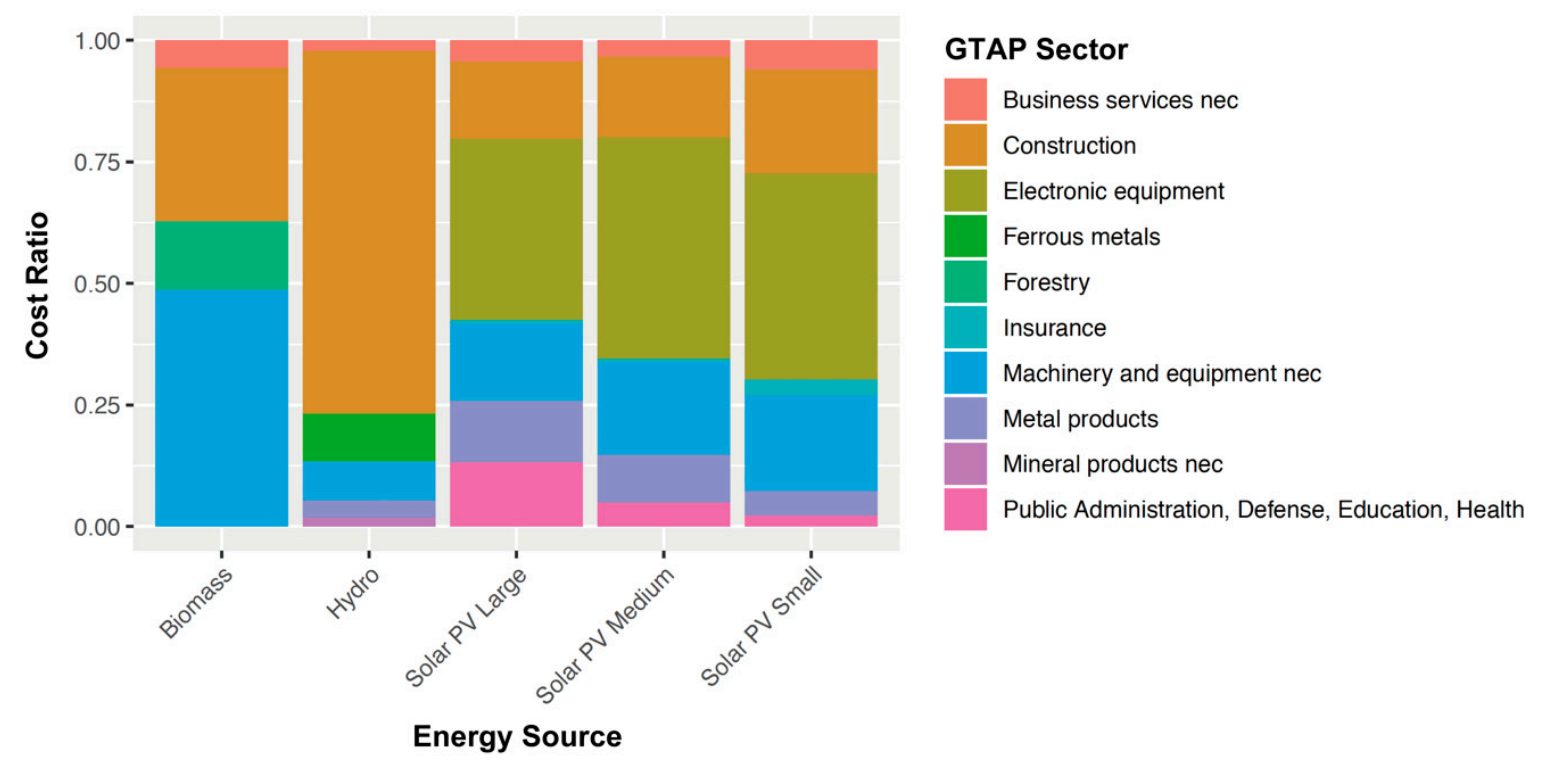

Figure 3. GTAP sector cost ratios of renewable electricity in Malaysia in 2016.

\section{Results}

\subsection{Social Life Cycle Impact Assessment}

The social impact of $1 \mathrm{kWh}$ of electricity from five renewable sources (biomass, solar PV small, solar PV medium, solar PV large, and hydro) as well as the conventional production mix were assessed with SHDB on openLCA 1.7.2. The calculated Risk Hours inventories were then weighted and converged into 24 Social Themes and 5 Social Categories with the Social Hotspot Index as illustrated in Figures 4 and 5. 


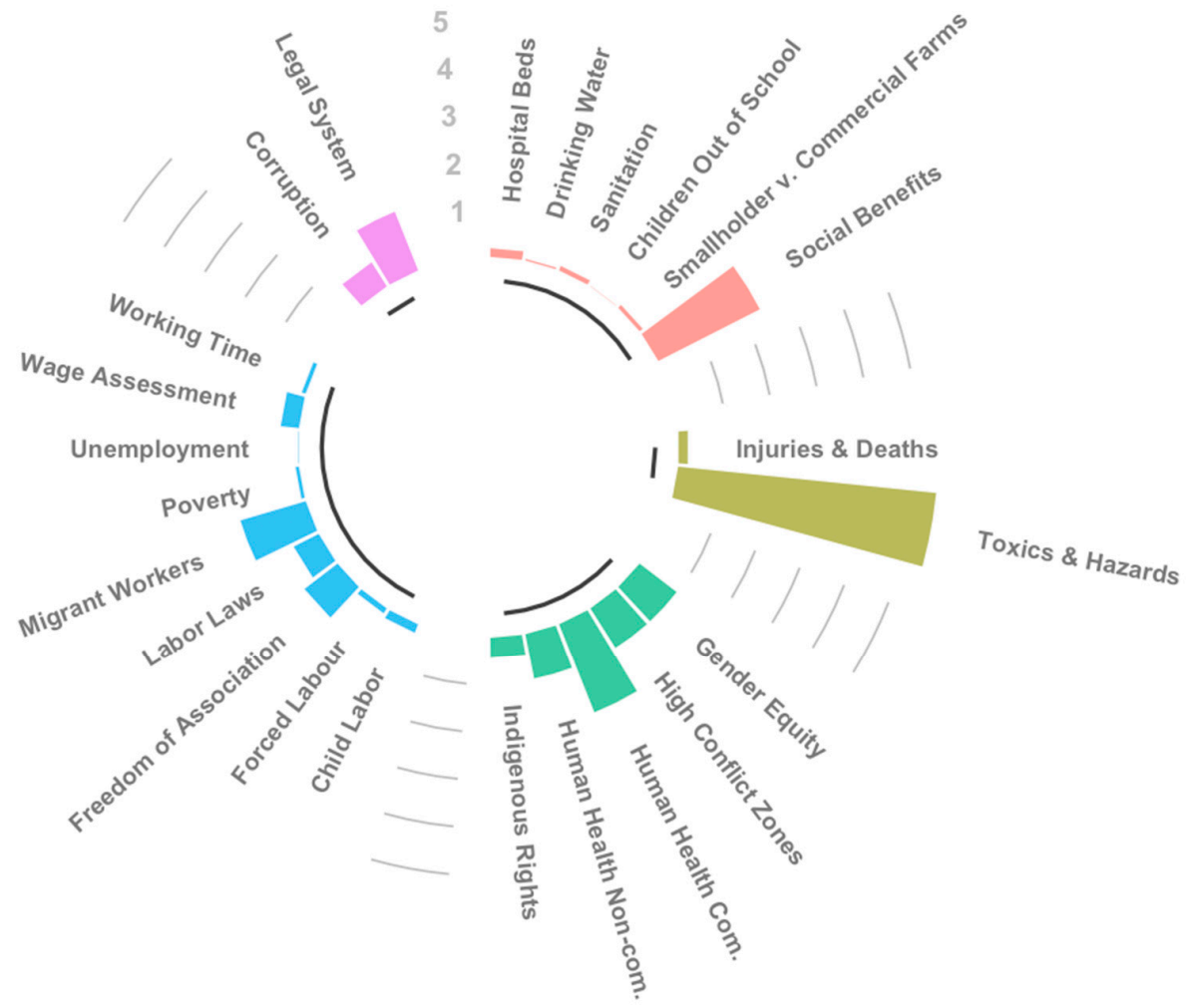

(a) Biomass

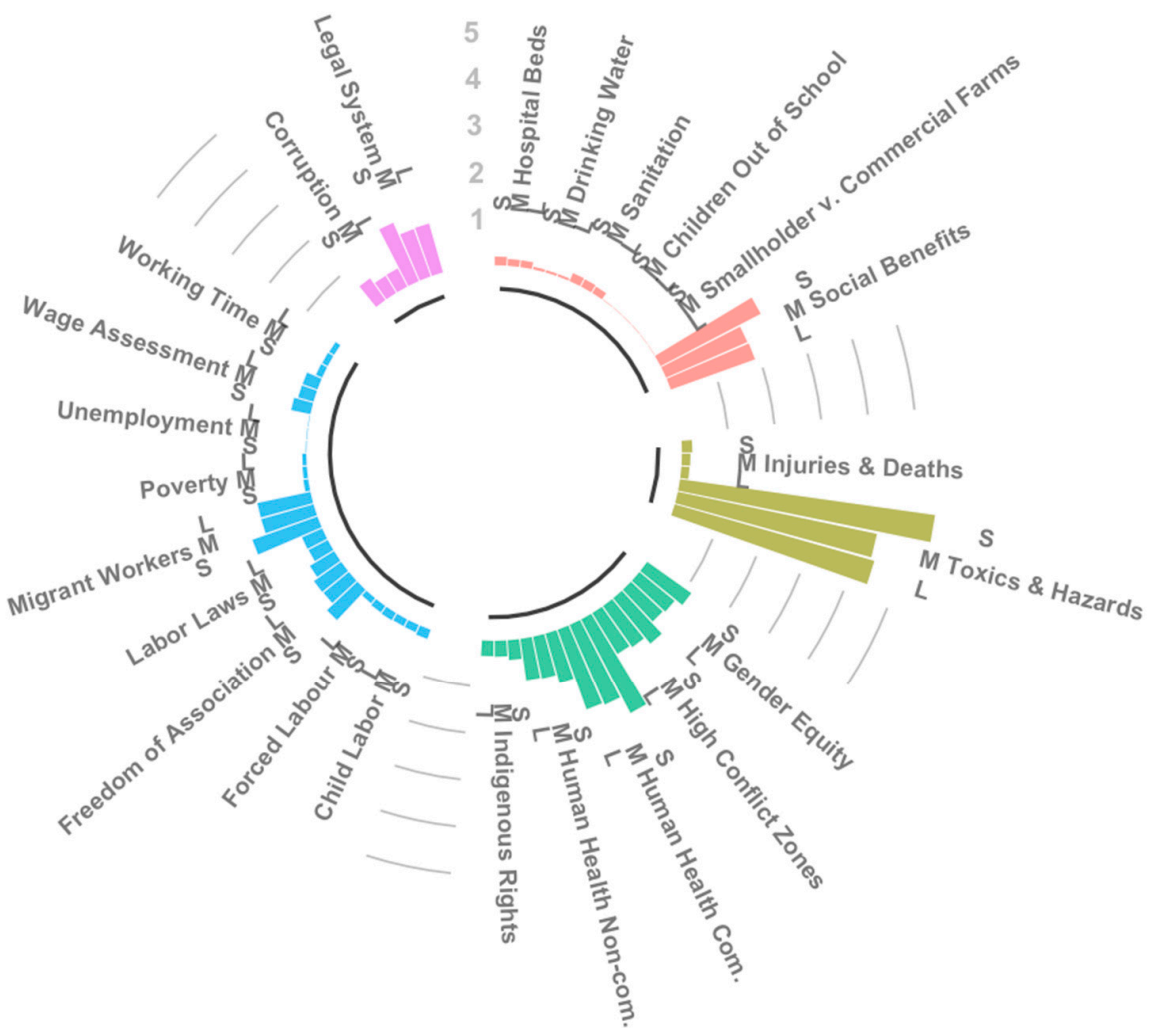

(b) Solar PV (S: below $100 \mathrm{~kW}$, M: between 100-1,000 kW, L: above $1 \mathrm{MW}$ )

Figure 4. Cont. 


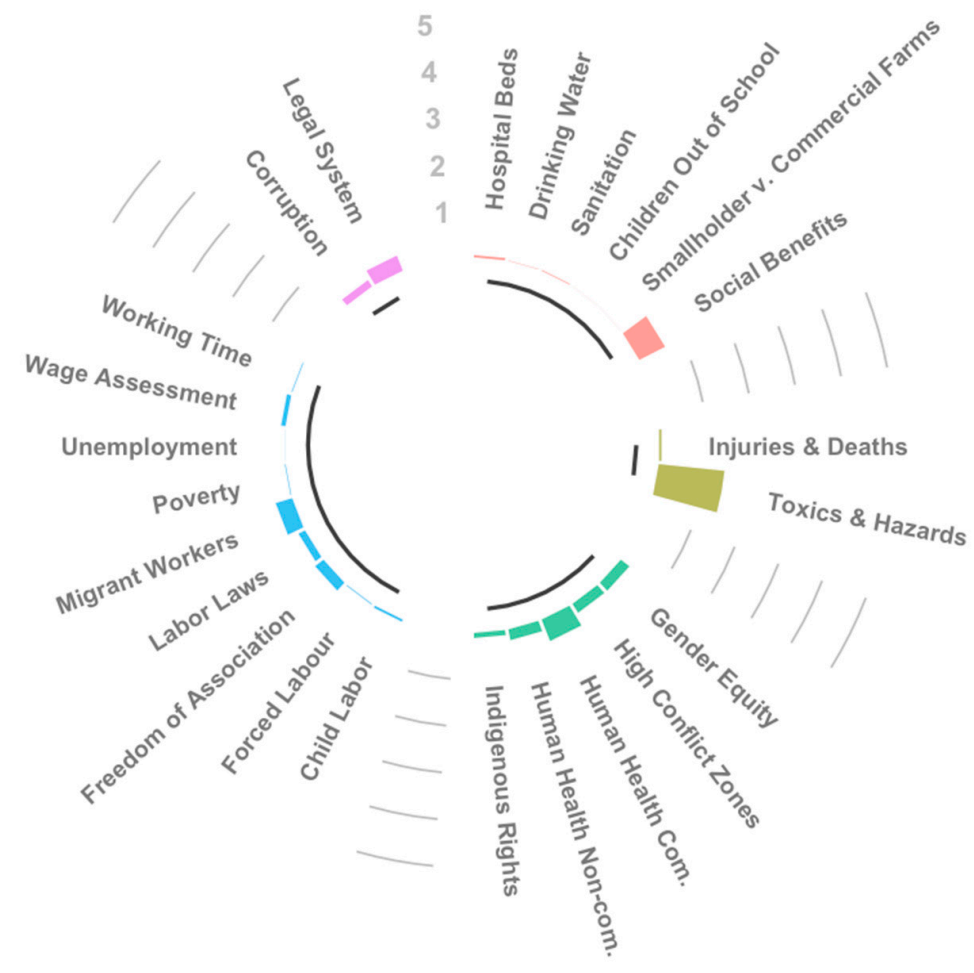

(c) Hydro

Figure 4. Midpoint life cycle impact assessment results: (a) Biomass; (b) Solar PV; (c) Hydro.

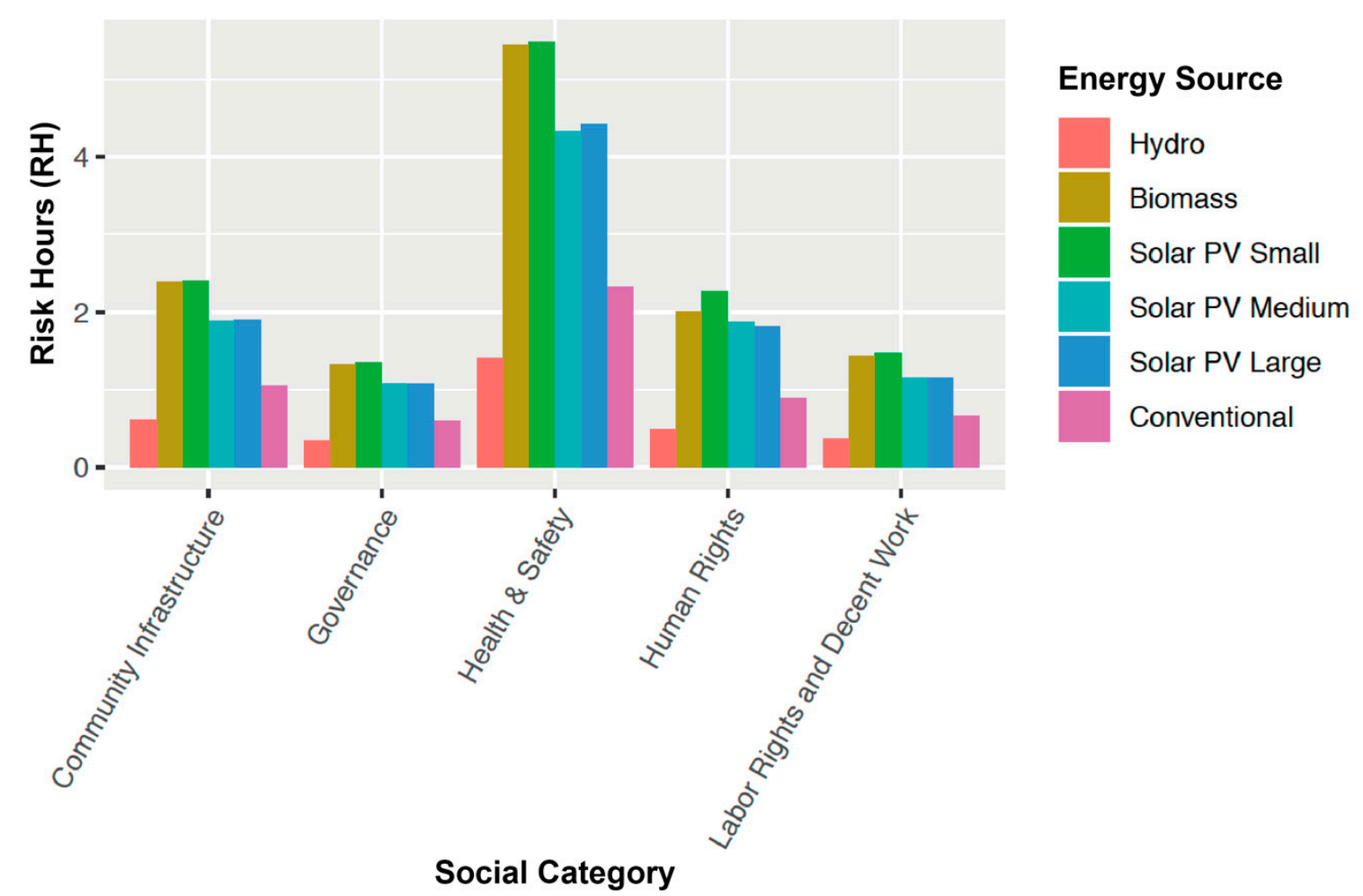

Figure 5. Comparison of social impacts of various electricity production method by Social Categories.

Figure 5 indicate that regardless of the energy sources, renewable electricity has similar social impact patterns: the health and safety category has the greatest adverse social impact in the supply 
chain due to the great impact from toxics and hazards. A similar pattern is also observed for the conventional electricity mix.

\subsection{Process and Country Contributions}

The calculated process and country contributions of biomass, solar PV and Hydro are illustrated in Figure $6 \mathrm{a}-\mathrm{c}$, respectively. Here, the areas for each process are drawn in proportion to the total Risk Hours of each sector/country.

Figure 6 shows that the construction in Malaysia is the largest social footprint contributor for both hydro and solar PV electricity. In particular, construction is responsible for more than $60 \%$ of the social footprint of hydroelectricity. For solar PV, electronic equipment and metals from China are the second largest contributor when combined, which reflects the fact that a large share of the solar panels, and its mounting parts come from China. Another large contributor to solar PV was the public administration in Malaysia, which reflects the licensing cost for a significant portion of the capital expenditures for solar PV plants in Malaysia. On the contrary, the largest social footprint contributor of biomass electricity came from the forestry in Malaysia, followed by the construction in Malaysia.

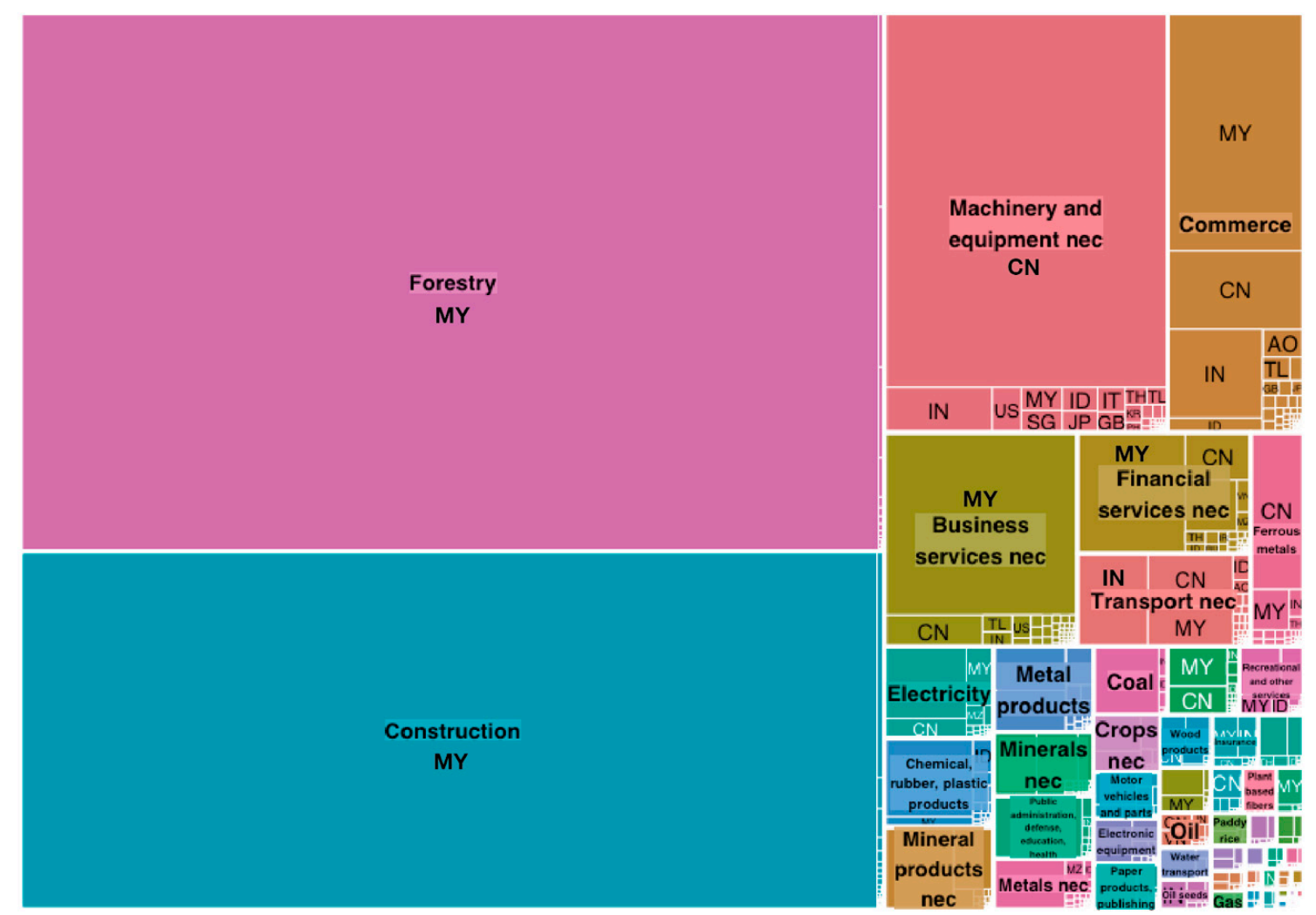

(a) Biomass

Figure 6. Cont. 


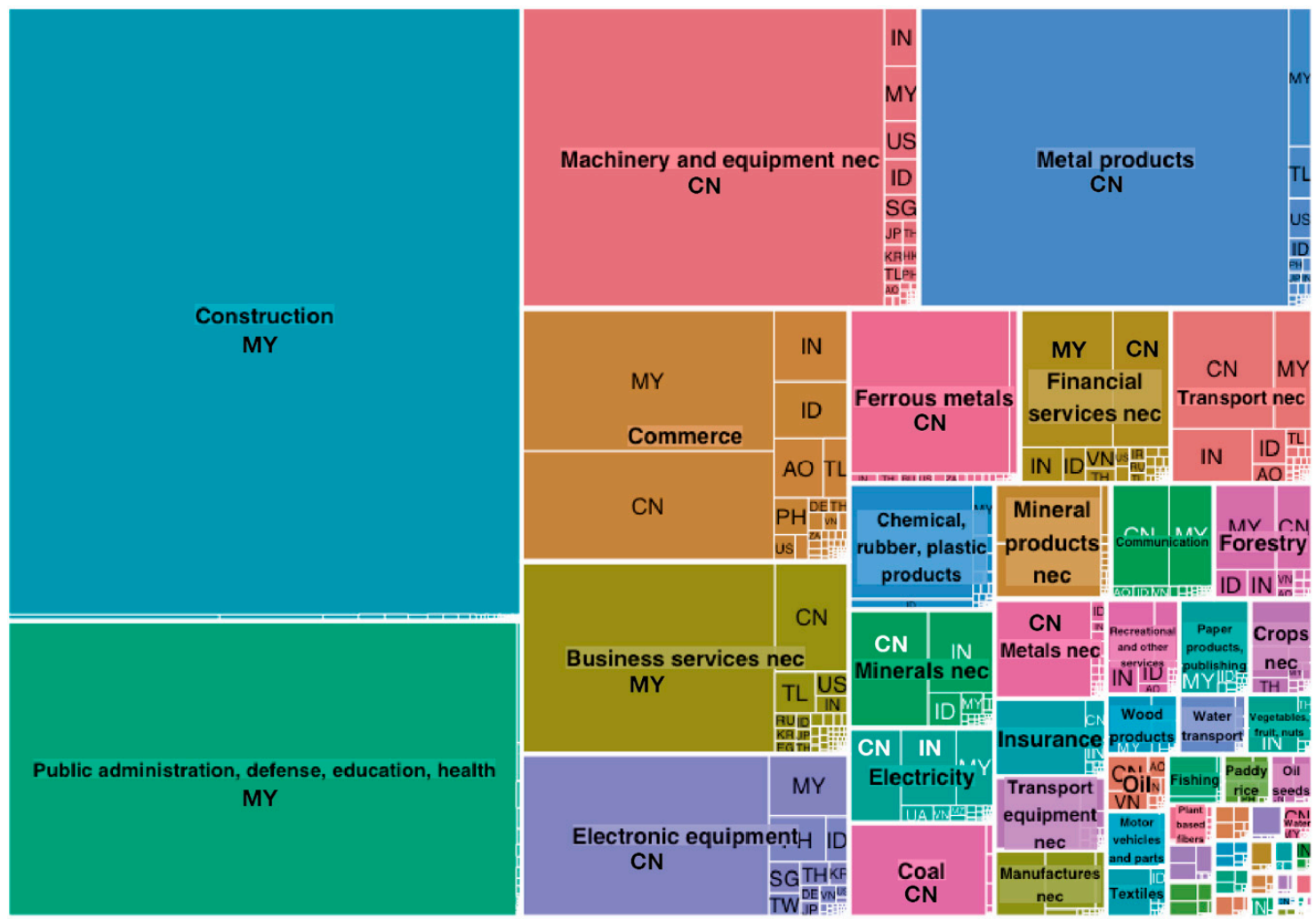

(b) Solar PV (Large)

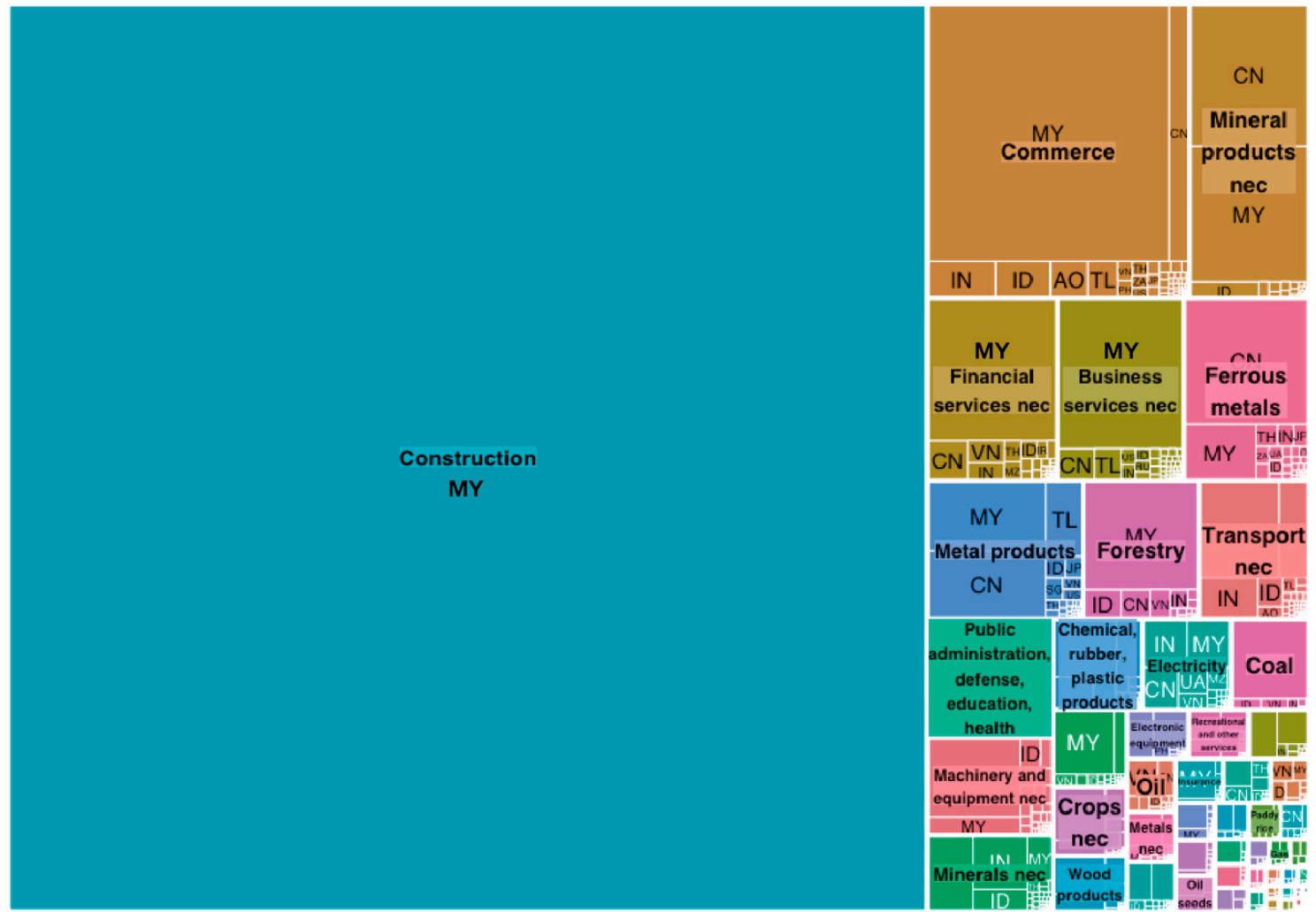

(c) Hydro

Figure 6. Process and country contributions: (a) Biomass; (b) Solar PV; (c) Hydro. (MY: Malaysia, CN: China, IN: India, ID: Indonesia). 


\section{Discussion}

\subsection{Normalized Social Footprint per Unit-Electricity vs. Unit-Cost}

Figure 7 shows the calculated normalized social footprint for each electricity source, (a) per $1 \mathrm{kWh}$ and (b) per 1 USD of generation cost. According Figure 7a, the electricity from renewables had a greater adverse social impact per unit-electricity than the conventional electricity mix per $\mathrm{kWh}$, except for hydroelectricity. Biomass (19.5 RH) exhibited 227\% of the social impact of conventional electricity (8.6 RH). Solar PVs exhibited differing degrees of social impact: small-scale solar PV (defined as $<100 \mathrm{~kW}$ output) had the greatest social impact among the five assessed renewable energy sources with $20.7 \mathrm{RH}$; mid-scale and large-scale solar PVs (defined as 100-1000 kW and > $1 \mathrm{MW}$, respectively) had a similar social impact with 16.7 and $16.6 \mathrm{RH}$, respectively, which are $14 \%$ less than biomass but $95 \%$ more than the conventional electricity mix per $1 \mathrm{kWh}$. Hydro, on the other hand, exhibited a significantly reduced social impact with $4.9 \mathrm{RH}$, which is $43 \%$ smaller than the conventional electricity mix.

This result may be mainly attributed to the high cost of renewable electricity. According to ASEAN Centre for Energy (2016), the costs of electricity for each energy source in Malaysia are as follows:

solar PV small $(\$ 0.20 / \mathrm{kWh})>$ solar PV medium $(\$ 0.17 / \mathrm{kWh})>$ solar PV large $(\$ 0.15 / \mathrm{kWh})$

>> biomass $(\$ 0.10 / \mathrm{kWh})>>$ conventional $(\$ 0.03 / \mathrm{kWh}) \sim$ hydro $(\$ 0.03 / \mathrm{kWh})$

As such, comparing the social impact per unit generation cost, rather than per unit electricity generated, reveals that the solar power plant is much less impactful than all other energy sources. These comparisons are illustrated in Figure 7b, where solar PV has a 60\% smaller social impact than conventional electricity per dollar spent, as follows:

conventional $(281.5 \mathrm{RH})>>$ biomass $(192.6 \mathrm{RH})>$ hydro $(168.6 \mathrm{RH})>>$ solar PV large

(110.5 RH) > solar PV small (103.5 RH) > solar PV medium (98.2 RH)

This comparison of social footprint per unit electricity vs. unit cost indicates that while the electricity from solar PV and biomass in Malaysia have a agreater adverse social impact than the conventional energy mix per unit electricity at present, labor conditions for these renewable electricity sources per unit cost are significantly better than those of conventional electricity generation. This suggests that when the generation costs of these renewable sources eventually drop and reach grid parity, the social impact of electricity generation will be mitigated through the development of these sources. 


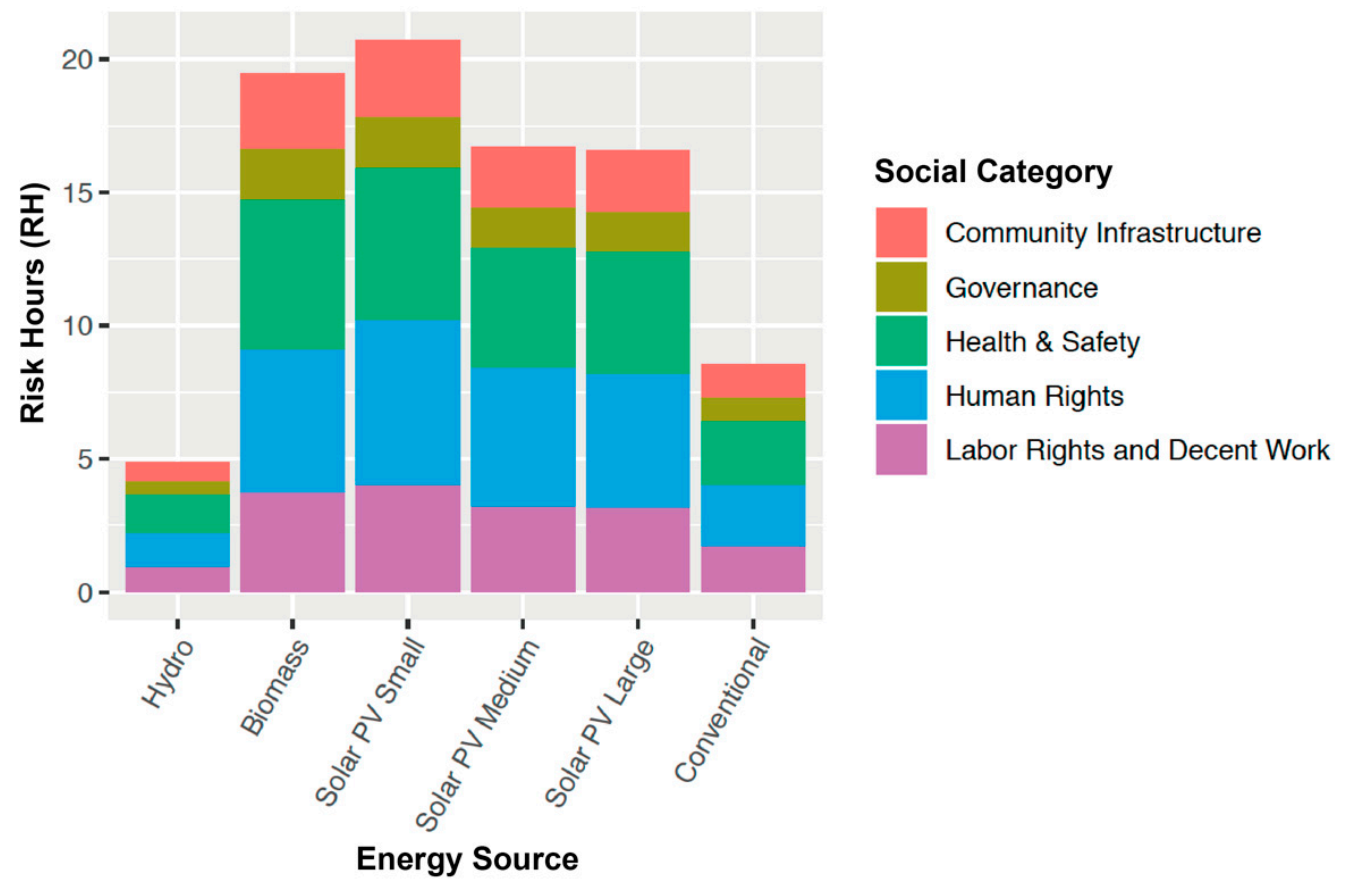

(a) Per $1 \mathrm{kWh}$ of Electricity

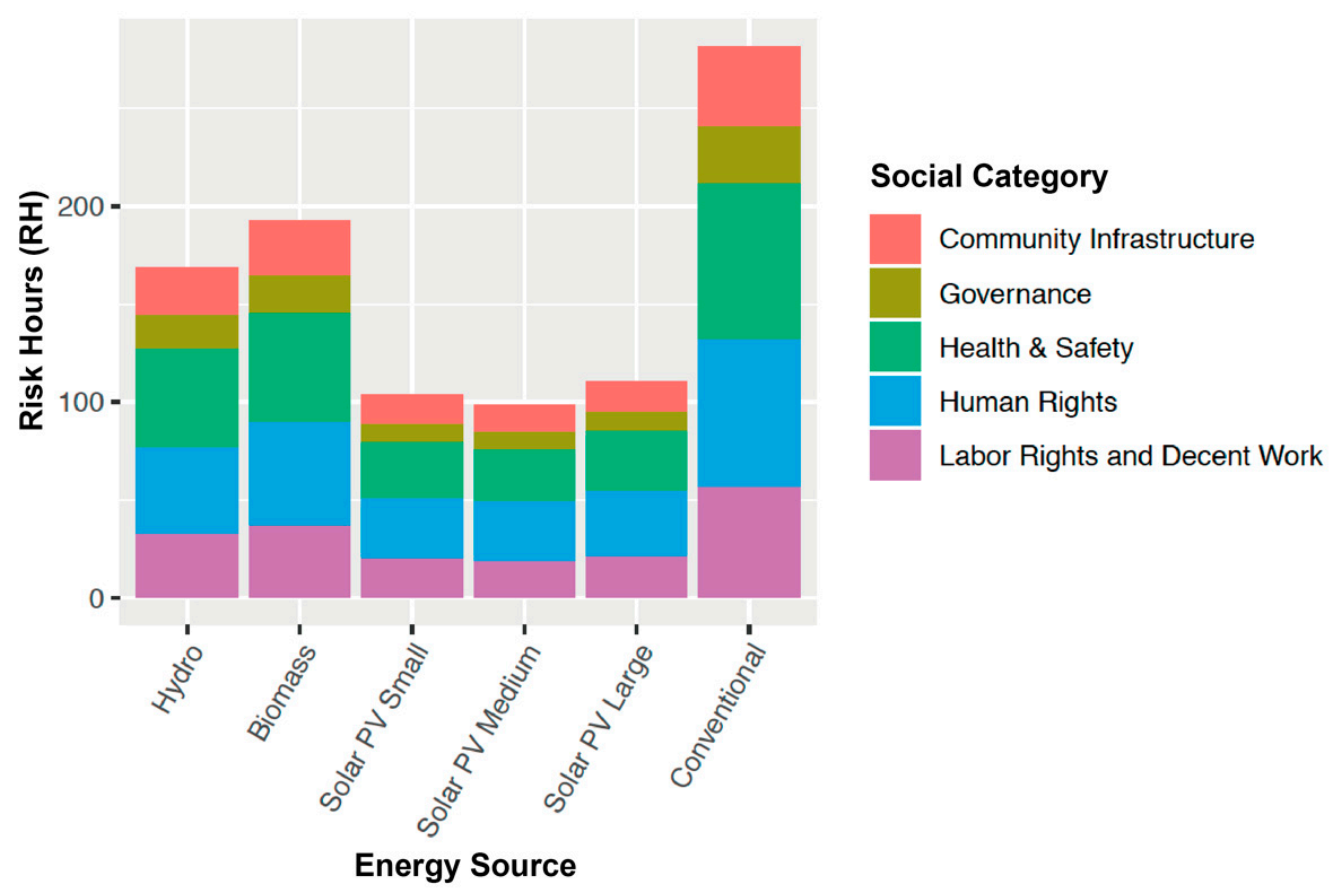

(b) Per 1 USD of generation cost

Figure 7. Normalized social footprints: (a) per unit electricity, (b) per unit cost.

\subsection{Geographical Social Hotspots of Renewable Electricity}

Figure 6 shows that a great proportion of the social footprint of renewable electricity came from outside of the country as a result of the global supply chain. Figure 8 illustrates the social footprint contribution proportions of China, the largest overseas contributor, and of Malaysia. 


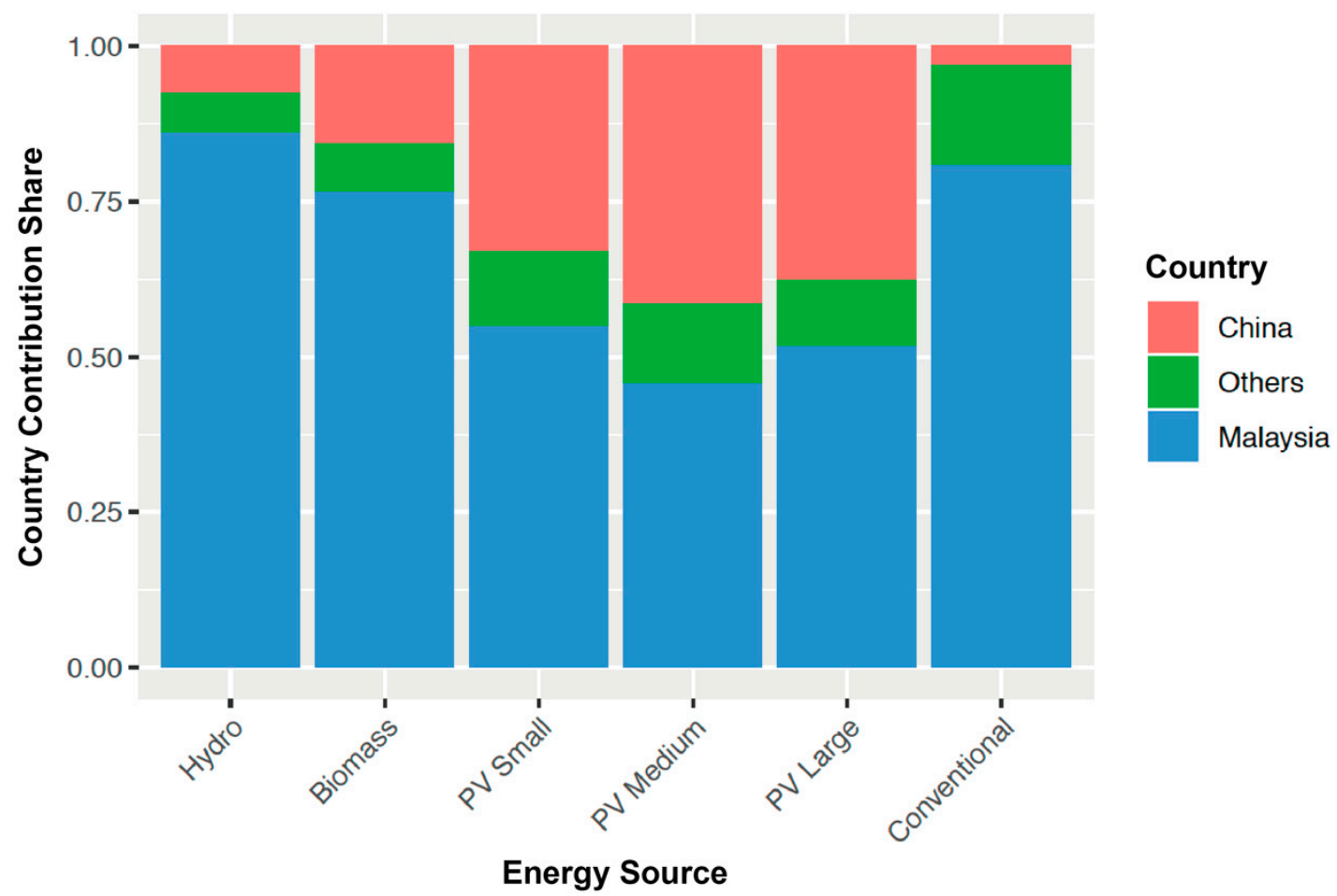

Figure 8. Geographical Social Hotspots of Renewable Electricity.

The results show that renewable electricity has a less adverse social impact domestically, while the effects are transferred to the exporting countries, in this case China. This indicates the possibility to improve the social impact of renewable electricity across the globe by improving labor conditions in a few exporting countries.

\section{Conclusions}

What do all these data suggest? Based on Figure $7 \mathrm{a}$, it can be concluded that electricity generation through renewable energy technologies causes significantly greater stress among workers, with the exception of hydroelectricity. However, on the other hand, when the social impacts per generation cost were compared, renewables had far lower impacts than the conventional electricity mix as illustrated in Figure $7 \mathrm{~b}$. This is a fascinating result, because it suggests that while renewables are not as friendly to humans as to the environment at the moment, they will have the potential to be much more favorable to humans than the conventional energy mix in the future when costs of renewable electricity eventually drop. In fact, it is estimated that when solar PV achieves grid parity in the future, labor conditions through the electricity supply chain will be as much as $60 \%$ less than the conventional electricity generation in Malaysia. It was also discovered that these adverse social effects are transferred to few exporting countries, including China, as illustrated in Figure 8. This could provide an opportunity to reduce the social impacts of renewable electricity across the nation, by improving labor conditions in a few exporting countries.

Are renewable energy technologies as friendly to humans as to the environment? Based on the findings, the authors conclude that the answer is, "not-yet, but eventually." This analysis suggests a clear path toward the reduction of the adverse impacts of renewables: to continue the efforts to reduce the cost of renewable energy technologies, while improving the labor conditions in key exporting countries like China.

Supplementary Materials: The following are available online at http:/ /www.mdpi.com/2071-1050/11/5/1370/s1, Table S1: Cost Structures and the Country of Origins Model: (a) Biomass; (b) Solar PV; (c) Hydro, Table S2: SHDB product models: (a) Biomass; (b) Solar PV; (c) Hydro. 
Author Contributions: Conceptualization, S.T.; methodology, S.T., A.R.K. and C.B.N; software, C.B.N; validation, S.T., S.S., A.R.K., S.M. and C.B.N.; formal analysis, S.T.; investigation, S.T. and A.R.K.; resources, S.T. and C.B.N.; data curation, S.T. and C.B.N.; writing—original draft preparation, S.T.; writing-review and editing, S.T. and A.R.K.; visualization, S.T.; supervision, S.S., S.M. and C.B.N.; project administration, S.T. and A.R.K.

Funding: This research was funded by Japan International Cooperation Agency (JICA) under JICA-Kyoto University joint research program "A Socio-economic Research on Sustainable Development of Renewable Energy Sources in Developing Countries."

Acknowledgments: The authors sincerely thank ASEAN Centre for Energy for providing invaluable comments and feedbacks based on the cooperative research agreement between Kyoto University and ASEAN Centre for Energy.

Conflicts of Interest: The authors declare no conflicts of interest.

\section{References}

1. Chatri, F.; Yahoo, M.; Othman, J. The economic effects of renewable energy expansion in the electricity sector: A CGE analysis for Malaysia. Renew. Sustain. Energy Rev. 2018, 95, 203-216. [CrossRef]

2. Dong, K.; Hochman, G.; Zhang, Y.; Sun, R.; Li, H.; Liao, H. $\mathrm{CO}_{2}$ emissions, economic and population growth, and renewable energy: Empirical evidence across regions. Energy Econ. 2018, 75, 180-192. [CrossRef]

3. Isik, C.; Dogru, T.; Turk, E.S. A nexus of linear and non-linear relationships between tourism demand, renewable energy consumption, and economic growth: Theory and evidence. Int. J. Tour. Res. 2018, 20, 38-49. [CrossRef]

4. Ludin, N.A.; Mustafa, N.I.; Hanafiah, M.M.; Ibrahim, M.A.; Asri Mat Teridi, M.; Sepeai, S.; Zaharim, A.; Sopian, K. Prospects of life cycle assessment of renewable energy from solar photovoltaic technologies: A review. Renew. Sustain. Energy Rev. 2018, 96, 11-28. [CrossRef]

5. Oh, T.H.; Hasanuzzaman, M.; Selvaraj, J.; Teo, S.C.; Chua, S.C. Energy policy and alternative energy in Malaysia: Issues and challenges for sustainable growth-An update. Renew. Sustain. Energy Rev. 2018, 81, 3021-3031. [CrossRef]

6. United Nations Environmental Programme and Society of Environmental Toxicology and Chemistry. Guidelines for Social Life Cycle Assessment of Products; UNEP: Nairobi, Kenya, 2011.

7. Aparcana, S.; Salhofer, S. Development of a social impact assessment methodology for recycling systems in low-income countries. Int. J. Life Cycle Assess. 2013, 18, 1106-1115. [CrossRef]

8. Arcese, G.; Lucchetti, M.C.; Merli, R. Social life cycle assessment as a management tool: Methodology for application in tourism. Sustainability 2013, 5, 3275-3287. [CrossRef]

9. De Luca, A.I.; Iofrida, N.; Strano, A.; Falcone, G.; Gulisano, G. Social life cycle assessment and participatory approaches: A methodological proposal applied to citrus farming in Southern Italy. Integr. Environ. Assess. Manag. 2015, 11, 383-396. [CrossRef] [PubMed]

10. Macombe, C.; Leskinen, P.; Feschet, P.; Antikainen, R. Social life cycle assessment of biodiesel production at three levels: A literature review and development needs. J. Clean. Prod. 2013, 52, 205-216. [CrossRef]

11. Benoît-Norris, C.; Vickery-Niederman, G.; Valdivia, S.; Franze, J.; Traverso, M.; Ciroth, A.; Mazijn, B. Introducing the UNEP/SETAC methodological sheets for subcategories of social LCA. Int. J. Life Cycle Assess. 2011, 16, 682-690. [CrossRef]

12. Mattila, T.J.; Judl, J.; Macombe, C.; Leskinen, P. Evaluating social sustainability of bioeconomy value chains through integrated use of local and global methods. Biomass Bioenergy 2018, 109, 276-283. [CrossRef]

13. Benoît-Norris, C.; Cavan, D.A.; Norris, G. Identifying social impacts in product supply chains: Overview and application of the social hotspot database. Sustainability 2012, 4, 1946-1965. [CrossRef]

14. New Earth. Introductory User Tutorial for Social Hotspots Database; New Earth Maine: York Beach, ME, USA, 2014.

15. Hashim, H.; Ho, W.S. Renewable energy policies and initiatives for a sustainable energy future in Malaysia. Renew. Sustain. Energy Rev. 2011, 15, 4780-4787. [CrossRef]

16. Murray, J.; McBain, D.; Wiedmass, T. (Eds.) The Sustainability Practitioner's Guide to Social Analysis and Assessment; Common Ground Publishing: Champaign, IL, USA, 2015.

17. Shemfe, M.; Gadkari, S.; Sadhukhan, J. Social Hotspot Analysis and Trade Policy Implications of the Use of Bioelectrochemical Systems for Resource Recovery from Wastewater. Sustainability 2018, 10, 3193. [CrossRef] 
18. Holger, S.; Jan, K.; Petra, Z.; Andrea, S.; Jürgen-Friedrich, H. The Social Footprint of Hydrogen Production-A Social Life Cycle Assessment (S-LCA) of Alkaline Water Electrolysis. Energy Procedia 2017, 105, 3038-3044. [CrossRef]

19. Muthu, S.S. (Ed.) Social Life Cycle Assessment: An Insight; Springer: Berlin, Germany, 2014.

20. ASEAN Centre for Energy. Levelised Cost of Electricity of Selected Renewable Technologies in the ASEAN Member States; ASEAN Centre for Energy: Jakarta, Indonesia, 2016.

21. Hausmann, R.; Hidalgo, C.A.; Bustos, S.; Coscia, M.; Chung, S.; Jimenez, J.; Simoes, A.; Yildirim, M. The Atlas of Economic Complexity; Puritan Press: Cambridge, UK, 2011.

2019 by the authors. Licensee MDPI, Basel, Switzerland. This article is an open access article distributed under the terms and conditions of the Creative Commons Attribution (CC BY) license (http://creativecommons.org/licenses/by/4.0/). 